\title{
Increasing the Life of Mulching Tools
}

\author{
V. L'UPTÁČIKOVÁ ${ }^{1}$, R. HNILICA ${ }^{2}$, M. ŤAVODOVÁ ${ }^{3}$ \\ ${ }^{1}$ Technical university in Zvolen, Faculty of environmental and manufacturing technology, \\ luptacikovav@gmail.com \\ 2Technical university in Zvolen, Faculty of environmental and manufacturing technology, hnilica@is.tuzvo.sk \\ ${ }^{3}$ Technical university in Zvolen, Faculty of environmental and manufacturing technology, tavodova@is.tuzvo.sk
}

Abstract. Areas after mining or calamity are not amenable to immediate afforestation and require some adjustment. After removal of wood biomass, the rest of the residue is scattered throughout the area. To modify them, Several methods can be used to remove it. The optimal conditions for the planting environment and the subsequent adaptation process of the planting can be achieved by its mechanical, biological, chemical treatment. The basic prerequisite for a successful renewal of forests is their release from undesirable increases, in some cases from foams (trees) from mining waste. The area is also released when forest nurseries, seed plantations, etc. are established. The main purpose of the release of surfaces is to achieve the maximum throughput of the area for the machines to be moved. They wear during work. Wearing is a permanently undesirable change in the surface due to the interaction of functional surfaces or functional surface and wear medium. A tool that does not have any editing can go into a state where it can no longer be used anymore. An experiment was carried out in which 9 new teeth were placed on the rotor of the crusher and their wear patterns were observed. The article shows the progress of tool wear over time.

\section{Introduction}

Forestry is characterized by a variety of natural conditions that need to be adapted to the selection and application of technological processes. The complexity of the production conditions is due to the fact that the production processes have been much longer than in the industrial sphere influenced by the high proportion of manual work [1].

The development of mechanization in forestry did not take place until the second half of the twentieth century, when mechanization facilities were gradually introduced for selected production phases, especially mining, concentrating, storage and handling of wood. This includes a very wide range of manufacturing technologies and workflows where progressive technical means can already be used. Research and development of technical solutions will achieve the desired result if the technical solutions respect natural, technological, economic and ergonomic requirements [2].

Before the planting itself, it is advisable to modify the site and thereby ensure good conditions for growing new seedlings. Soil preparation before afforestation is the basic workflow through which we create optimal planting and crop growth ratios [3]. 


\section{Material and methods}

The basic mechanized treatment of the terrain and the preparation of the soil for the foundation and upbringing of the forest include cultivation of the environment, soil processing and incorporation of forest biomass into the soil, thus improving the soil. Adapters used to process stagnant forest biomass are unwanted shredders (mulchers) [2].

The basic adapters that are mostly used in forestry activities are crushers of undesirable increases (Figure 1).
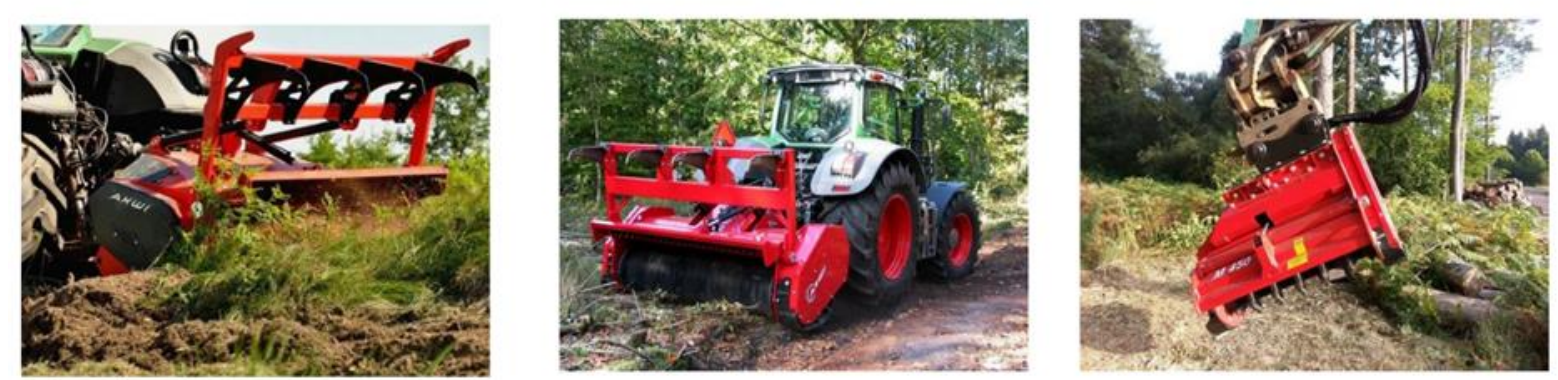

Figure 1. Crushers (KARLOW - KARLSHOF Company)

The most widely spread are crushers with a horizontal axis. The horizontal shaft rotor has free working tools that can be of different shapes:

- beads (Figure 2a),

- Hammers (Figure 2b),

- Teeth (Figure 2c).

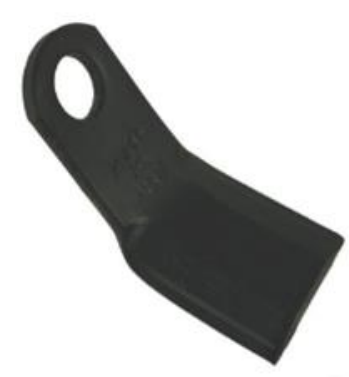

a)

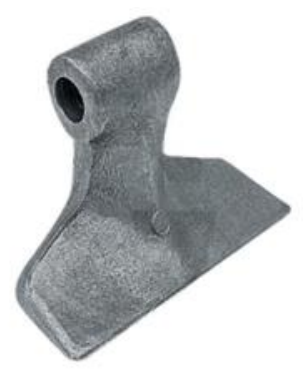

b)

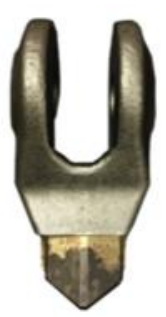

c)

Fig. 2 Mulching tools (KRAMP and GLOBAL TEETH) a) ceps, b) hammers, c) teeth

The crusher works in an environment where it is supposed to dispose of the plant, but at the same time it can also work in the environment of the soil the surface layer of which is to be disturbed. The properties of these two environments place quite contradictory requirements on the cutting tools themselves, which are essentially the executive elements of the crusher [7]. When cutting in a plant environment, the energy requirement is the most important requirement of their sharpness. With the gradual dampening of the brims, the energy intensity of chopping is rapidly increasing, with the quality of work decreasing [4]. The blades are swappable and allow crushing of undesirable woody 
rains, landscaping, and forest crushing. Crushers have cutting tools pivoted or firmly attached to a massive drum. In the rear there is a woodcutter with mechanically or hydraulically controlled rear cover [5].

Wearing is a permanently undesirable change in the surface due to the interaction of functional surfaces or functional surface and wear medium. It appears to be removing or moving particles from the worn surface by mechanical effects, possibly accompanied by other influences (eg chemical, electrochemical, electrical) [6]. Wear as a process of material loss from the surface of one or both of the rigid body contact surfaces occurs in all kinds of relative movement. It belongs to degradation processes [7].

One of the very intensive degradation processes is the wear of the material by the action of hard, predominantly mineral particles. More than $50 \%$ of all material wear is caused by abrasion [8].

We can use several different ways to increase the wear resistance of materials. In this chapter, the most frequently used methods are mentioned, which include, in particular, heat treatment, application of the layers to the base material and application of additional material to the base material.

Heat treatment is the modification of material properties by changing their structure, mainly by temperature and controlled cooling. The temperature must have a precisely prescribed and controlled value and time course with respect to the chemical composition of the material [9]. The thermal processing processes used in the technical practice according to Kalincová, D. are divided into 4 basic groups: annealing, quenching and tempering, chemical-heat treatment and thermo-mechanical processing [10].

The cost of replacing components that have been worn or damaged during use has led to the development of a wide range of methods known as welding, whereby parts can be returned to their usable state. In many cases, such repairs have a longer service life than the original work, because wear-resistant welding may be used as the original material [11].

Using welding, we protect parts exposed to wear of different types in order to obtain resistance against a certain type of wear or some specific properties. Although welding is primarily used to restore wear parts to a usable state to extend their service life, it is often expedient to use this technology to produce new parts. The actual workpiece can thus be made from a cheaper material and the surface properties are achieved by welding the weld metal, the properties of which are suitable for use under the given conditions [12].

\section{Results}

The unwanted growth tool consists of three parts: tool body, Tooth tool, soldering. A tool that does not have any editing can go into a state where it can no longer be used anymore. We have created a 3D Scan of a new two-gear tool and a double tooth tool of the shredder, which shows the tool wear rate when folded from the crusher's rotor. These scans were subsequently overlaid (Figure 3). The same procedure is then applied to the one-shot tool. 

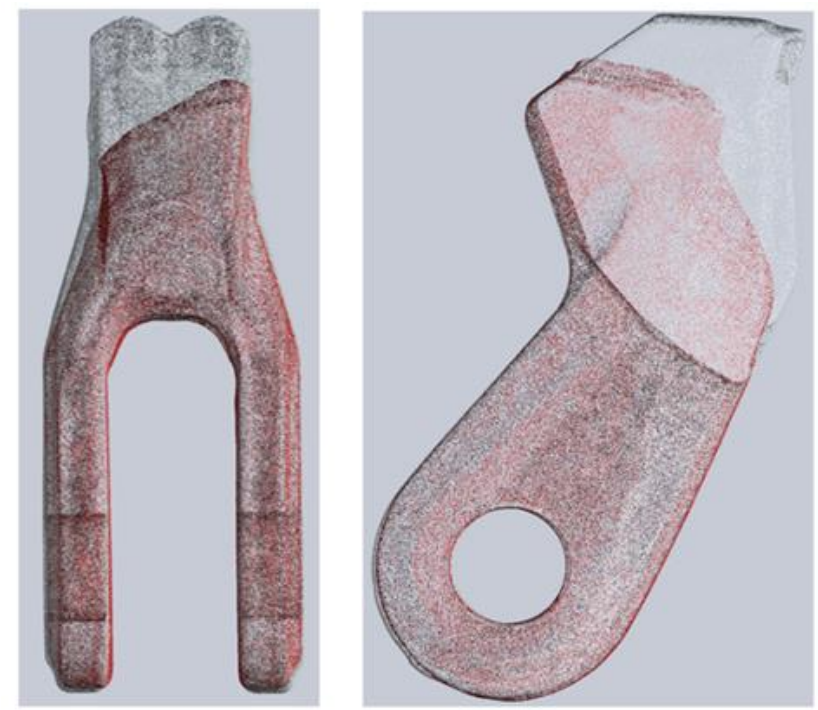

Figure 3. Loss of material shown on the two-gear tool

An experiment was carried out in which 9 new teeth were placed on the rotor of the crusher (Figure 4) and their wear patterns were monitored. The tools were numbered from 1 to 9 for experiment purposes, so that the tool was completely left on the number 1, the tool moved one point to the right, number 2, etc. to the last position in the row of the rotor.

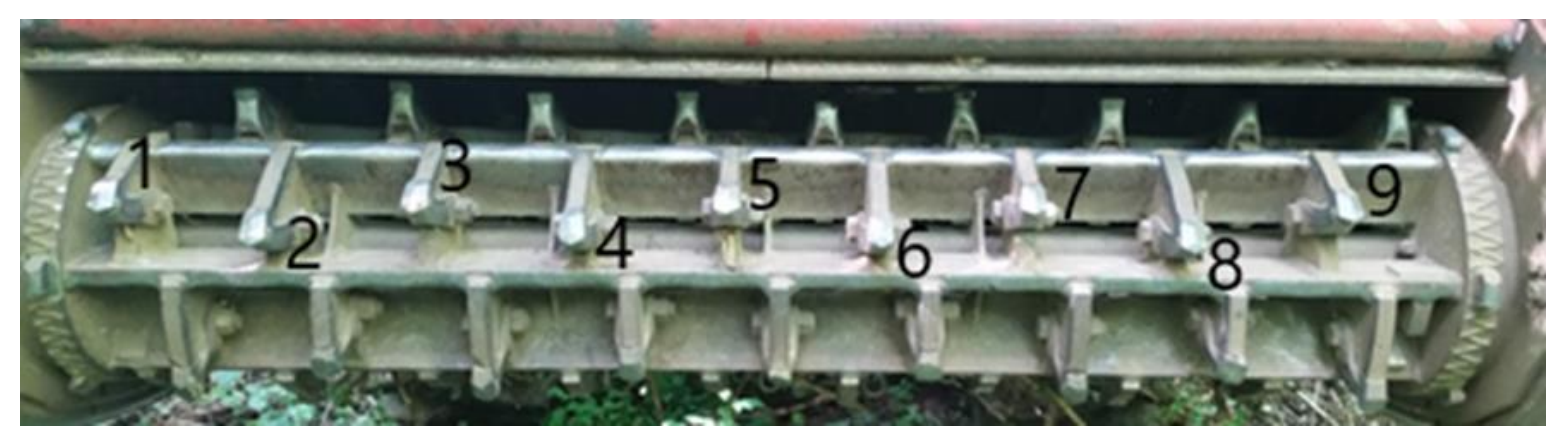

Figure 4. Rotor of the unwanted increase

With regular maintenance and inspection, it is not necessary to exchange all the tools at once, but only those that are so badly damaged that their working function is reduced to an unacceptable degree. Sometimes it happens that the tooth breaks on the tool and loses it. Such a tool is no longer usable. This is the case for the experiment 4 and 5 for the experiment. We will also try to use the tool again, which we would like to achieve by applying appropriate ways to increase life. The tool wear process at the time of the selected day is shown in Table 1. 
International Journal of Engineering and Management Sciences (IJEMS) Vol. 4. (2019). No. 1

DOI: 10.21791/IJEMS.2019.1.51.

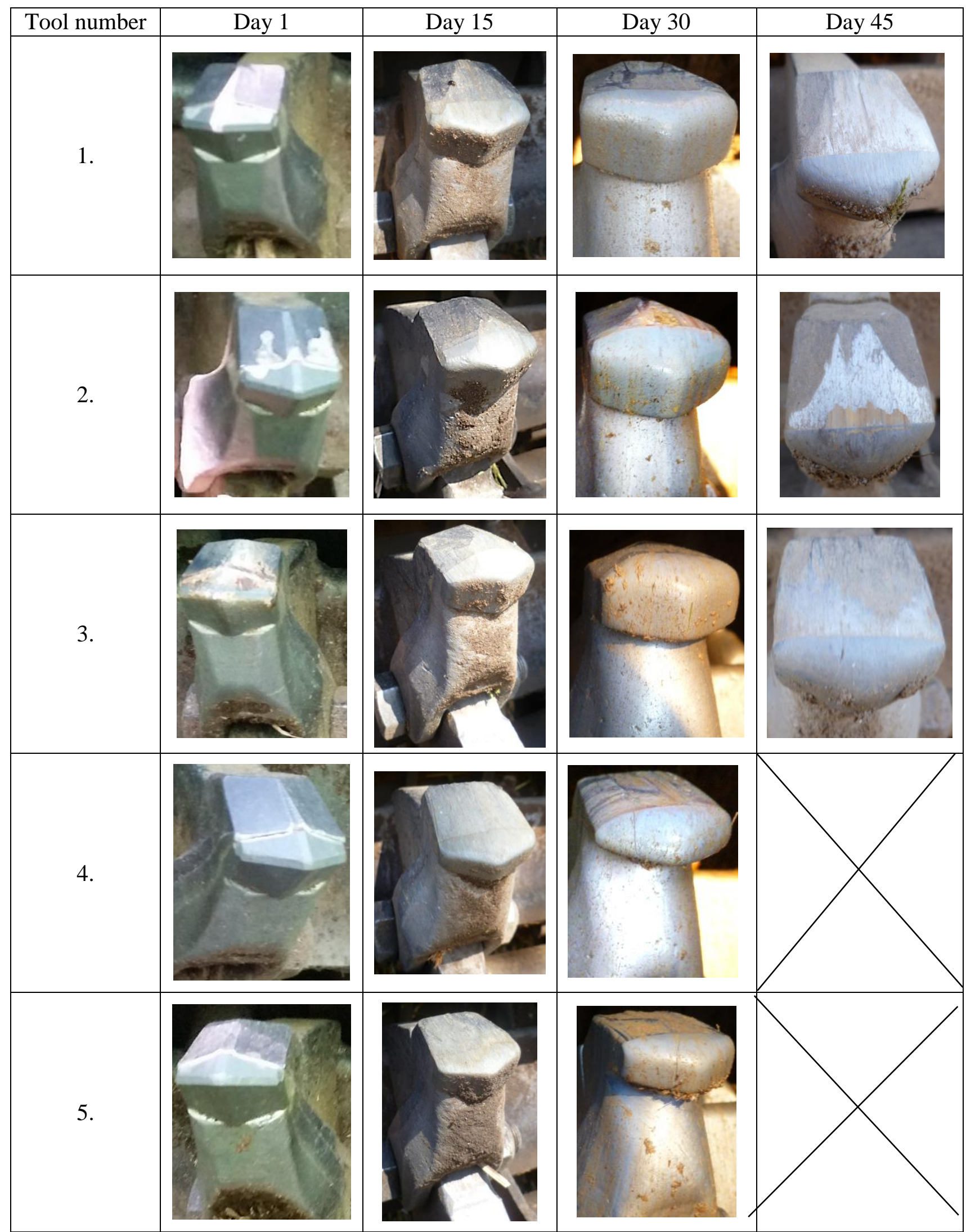


International Journal of Engineering and Management Sciences (IJEMS) Vol. 4. (2019). No. 1 DOI: 10.21791/IJEMS.2019.1.51.

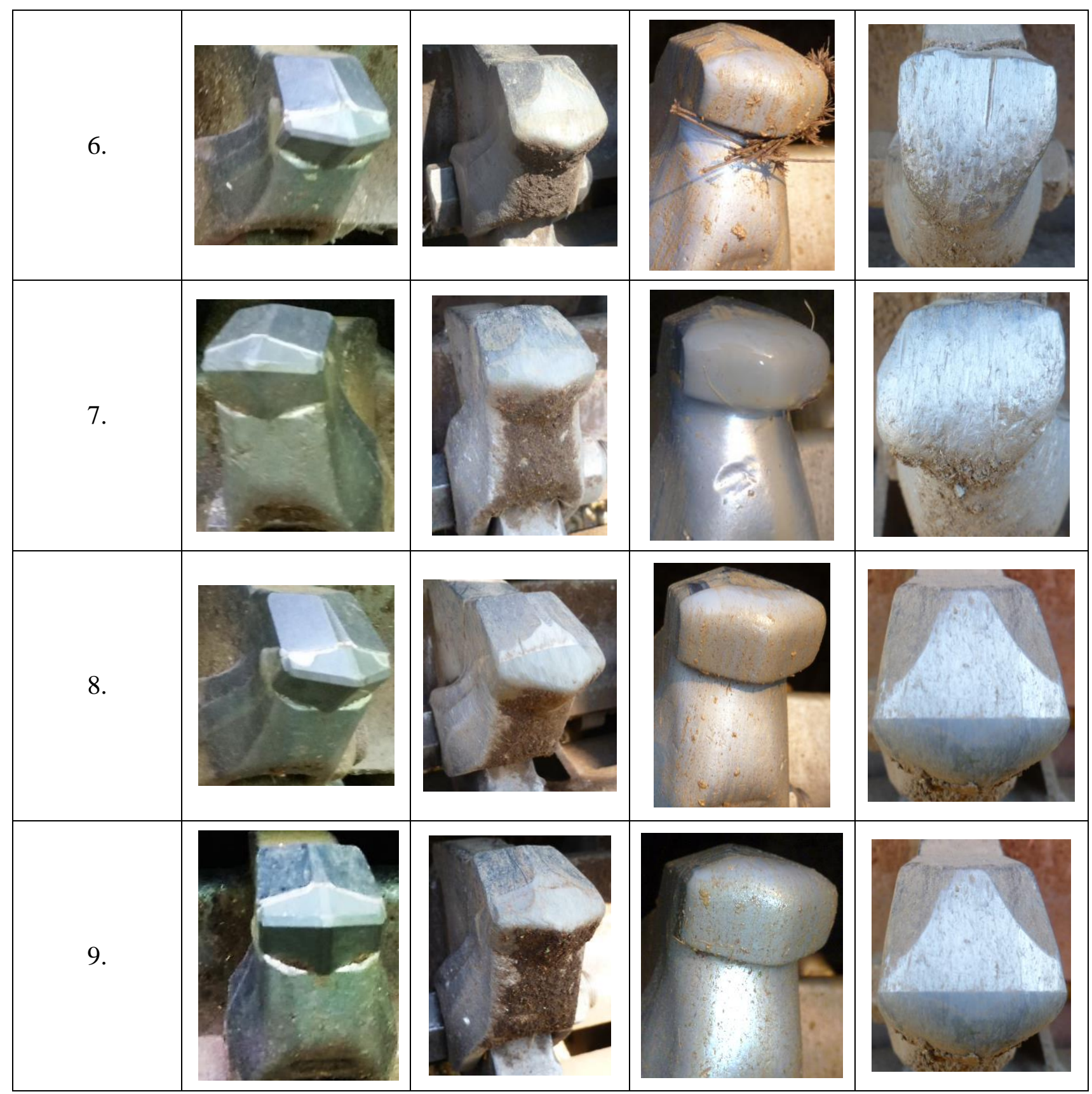

Table 1. Ways of tool wear over time

At 34 days, teeth 4 and 5 were so damaged that they had to be replaced on the rotor (Table 2). On tool 4 , it is also possible to see the tool tear break and its part loss. 


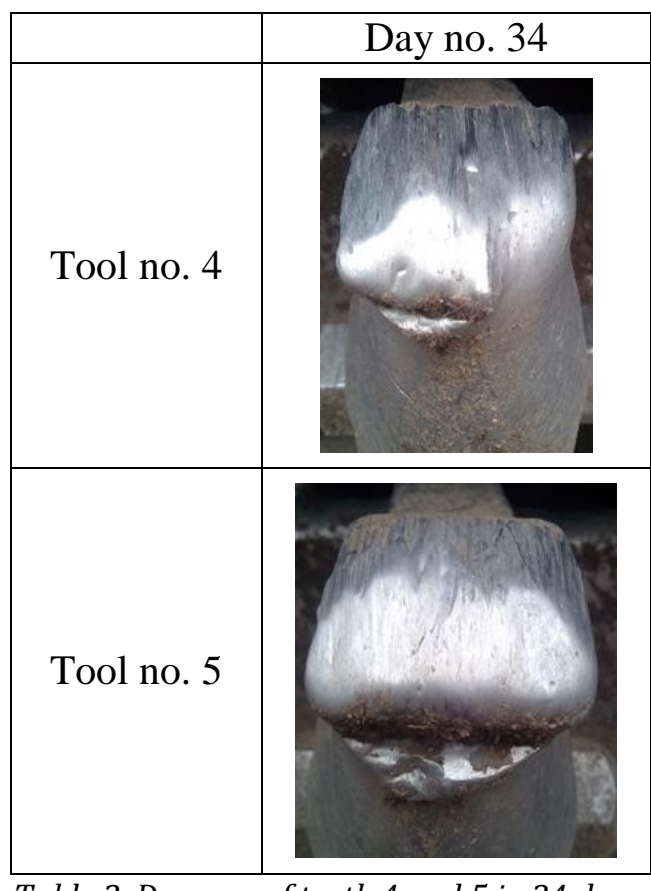

Table 2. Damage of teeth 4 and 5 in 34 days.

\section{Discussion}

From the experiment, we found that tool wear on the rotor is not uniform. This means that the wear rate of the tool in the center of the rotor and the edges is different.

Upon completion of these simulations and preliminary measurements, selection of appropriate lifecycle methods, their application and subsequent use in practice will be followed. We will analyze the findings.

\section{Conclusion}

The current situation in forestry requires the use of forestry tractors as carriers of multipurpose adapters. Forestry tractors have so far been regarded as machines only suitable for skidding. Recently, it has begun to reflect on the fact that, thanks to its patency and sloping accessibility, this base machine is also suitable as an adapter carrier.

The article presented ways to increase the lifetime of tools used in forest education, specifically mulch tools. We have devoted ourselves to the present state of matter, the wear and tear that is defined by the norm. We have also devoted ourselves to the methods we can use to increase their service life. In this way, our research will also be directed to increasing the life of unwanted tool crushers.

Experiments with untreated mulching tools have been performed. It has been discovered when the tool is damaged and its replacement is necessary. 


\section{Acknowledgments}

The described work was carried out as part of a project APVV-16-0194, Research on the Impact of Innovation in Production Processes on the Life of Tools and Components of Forest Mechanisms.

\section{References}

[1] M. Schwarz - E. Michalková - V. Lalík (2013) Environmentálne problémy v priemysle a t'ažbe: vysokoškolská elektronická učebnica. 1. vyd. Zvolen: Technická univerzita vo Zvolene. 337 p. ISBN 978-80-228-2546-7.

[2] M. Hnilicová - V. Messingerová - M. Dado (2013). Aplikácia pôdnej frézy ako adaptéra pre lesné kolesové traktory. Acta facultatis technicae: vedecký časopis Fakulty environmentálnej a výrobnej techniky.18 (2) pp. 67-74. ISSN 1336-4472.

[3] R. Hnilica - V. Messingerová - J. Stanovský - J. Slugeň - M. Hnilicová - M. Ferenčík (2015) Možnosti mechanizácie prác pri zakladaní a výchove lesa. Zvolen: Technická univerzita vo Zvolene. 97 P., ISBN 978-80-228-2722-5.

[4] Kováč, J., Krilek, J., Jobbágy, J., Dvořák, J., 2017. Technika a mechanizácia v lesníctve, 2017. 354 s., ISBN 978-80-228-3021-8.

[5] V. L’uptáčiková (2016) Kategorizácia drvičov z hl'adiska spracovaných priemerov nárastov. In Kolokvium ku grantovej úlohe č. 1/0826/15: vedecký recenzovaný zborník. Zvolen: Technická univerzita vo Zvolene. pp. 90 - 96, ISBN 978-80-228-2620-5.

[6] STN 01 5050: 1968 Opotrebenie materiálov. Názvoslovie.

[7] M- Ťavodová - D. Kalincová - M. Hnilicová (2016) The influence of heat treatment on tool properties mulcher. Manufacturing technology: journal for science, research and production. 5 pp. 1169-1173. ISSN 1213-2489.

[8] J. Suchánek (2009) Abrazivní opotrebenení kovových materiálů. 2009. [online], [cit. 05. 12. 2017]. Dostupné na internete: <http://www.tribotechnika.sk/.

[9] R. Rusnák (2015) Tepelné spracovanie nástrojových ocelí. Böhler Uddeholm. [online], [cit. 23. 02. 2018]. Dostupné na internete: <http://www.staton.sk/wpcontent/uploads/2015/04/S08_Rusnak_BU.pdf>.

[10] D. Kalincová - M. Ťavodová - M. Hnilicová - D. Veverková (2016) Machinery for forest cultivation - increase of resistance to abrasive wear of the tool. MM science journal. pp. 1269-1272. ISSN 1803-1269.

[11] P. Blaškovič - M. Čomaj (2006) Renovácia naváraním a žiarovým striekaním. Bratislava: Vydavatel'stvo STU v Bratislave. 204 p. ISBN 80-227-2482-3.

[12] Príručka zvárania pri údržbe a opravách, 2013. ESAB Slovakia, s. r. o. 